\title{
Epifaunal disturbance by periodic low levels of dissolved oxygen: native vs. invasive species response
}

\author{
E. B. Jewett ${ }^{1,2, *}$, A. H. Hines ${ }^{2}$, G. M. Ruiz ${ }^{2}$ \\ ${ }^{1}$ Department of Biology, University of Maryland, College Park, Maryland 20742, USA \\ ${ }^{2}$ Smithsonian Environmental Research Center, 647 Contees Wharf Road, Edgewater, Maryland 21037, USA
}

\begin{abstract}
Hypoxia is increasing in marine and estuarine systems worldwide, primarily due to anthropogenic causes. Periodic hypoxia represents a pulse disturbance, with the potential to restructure estuarine biotic communities. We chose the shallow, epifaunal community in the lower Chesapeake Bay, Virginia, USA, to test the hypothesis that low dissolved oxygen (DO) $\left(<4 \mathrm{mg} \mathrm{l}^{-1}\right)$ affects community dynamics by reducing the cover of spatial dominants, creating space both for less dominant native species and for invasive species. Settling panels were deployed at shallow depths in spring 2000 and 2001 at Gloucester Point, Virginia, and were manipulated every 2 wk from late June to mid-August. Manipulation involved exposing epifaunal communities to varying levels of DO for up to $24 \mathrm{~h}$ followed by redeployment in the York River. Exposure to low DO affected both species composition (presence or absence) and the abundance of the organisms present. Community dominance shifted away from barnacles as level of hypoxia increased. Barnacles were important spatial dominants which reduced species diversity when locally abundant. The cover of Hydroides dianthus, a native serpulid polychaete, doubled when exposed to periodic hypoxia. Increased $H$. dianthus cover may indicate whether a local region has experienced periodic, local DO depletion and thus provide an indicator of poor water-quality conditions. In 2001, the combined cover of the invasive and cryptogenic species in this community, Botryllus schlosseri (tunicate), Molgula manhattensis (tunicate), Ficopomatus enigmaticus (polychaete) and Diadumene lineata (anemone), was highest on the plates exposed to moderately low DO $\left(2 \mathrm{mg} \mathrm{l}^{-1}<\mathrm{DO}<4 \mathrm{mg} \mathrm{l}^{-1}\right)$. All 4 of these species are now found worldwide and exhibit life histories well adapted for establishment in foreign habitats. Low DO events may enhance success of invasive species, which further stress marine and estuarine ecosystems.
\end{abstract}

KEY WORDS: Periodic hypoxia · Invasive species · Chesapeake Bay · Disturbance · Epifauna

Resale or republication not permitted without written consent of the publisher

\section{INTRODUCTION}

Hypoxia in marine and estuarine environments is increasing worldwide as a result of high nutrient runoff from agriculture and urban development (Diaz \& Rosenburg 1995). In the US, $50 \%$ of estuaries now experience some hypoxia each year (Diaz 2001). Eutrophication, which fuels hypoxia in many systems, is a growing problem in the Baltic, Black and Mediterranean Seas, and along the coastlines of North and South America, Africa, India, SE Asia, Australia, China and Japan (Nixon 1990). Water-column stratification by salinity and temperature coupled with weak tidal mixing, a deep central channel and eutrophication make Chesapeake Bay particularly vulnerable to hypoxic and anoxic conditions in the summer (Officer et al. 1984). However, periodic low dissolved oxygen in shallow-water habitats may occur: (1) when hypoxic bottom waters move onshore during wind events, (2) as a result of a strong thermocline in nearshore waters (Breitburg 1990, Sanford et al. 1990), or (3) due to organic enrichment (Pearson \& Rosenberg 1978, Powilleit \& Kube 1999, Gray et al. 2002). Shallow embayments with restricted water circulation due to man- 
made structure are particularly vulnerable to temperature fluctuations that can lead to depleted DO at or near the surface (Breitburg 1990).

The spatial and temporal scale of hypoxia in Chesapeake Bay is well-studied. Large proportions of bottom water in the mainstem and tributaries becomes hypoxic every summer for periods lasting hours to months (Sanford et al. 1990). During summer, $62 \%$ of the subpycnocline water-volume in the mainstem has $<5 \mathrm{mg} \mathrm{l}^{-1}$ DO and about $19 \%$ has $<2 \mathrm{mg} \mathrm{l}^{-1}$ DO (Decker et al. 2004). However, less is understood about the extent to which low DO $\left(<4 \mathrm{mg} \mathrm{l}^{-1}\right)$ occurs in nearshore, shallow water. Breitburg (1990) recorded DO below $4 \mathrm{mg} \mathrm{l}^{-1}$ at $4 \mathrm{~m}$ depth on $83 \%$ of studied days at a western shore site in 1988 . How long these shallow low DO episodes persist or the extent of the geographic area affected is not well understood.

Multiple studies in the Chesapeake Bay, the Baltic Sea and along the coast of Japan have indicated a relationship between low DO and the condition of the benthos (Llanso 1992, Diaz \& Rosenberg 1995, Dauer et al. 2000, Suzuki 2001, Karlson et al. 2002). Dauer et al. (2000) found that $42 \%$ of the variation in the bottom benthos was explained by relative frequency of lowDO events. Few experiments, however, have tried to isolate the changes directly attributable to low DO vs. other correlated physical properties. In addition, more studies have focused on the effects of hypoxia on recruitment (Breitburg 1992, Sagasti et al. 2000, 2003) and on single species tolerance (Sagasti et al. 2001, Gray et al. 2002) without considering the effects on the entire community (Llanso 1992). The question of how single species tolerances scale-up to community change is less clear.

The manner in which episodic disturbance by low DO events structures the estuarine epifaunal community of Chesapeake Bay is complex. Low DO disturbance has the ability to open up space through killing or stressing the resident fauna and to change community processes such as predation (Brante \& Hughes 2001) and competition (Johnston \& Keough 2003). A species is benefited if it has a higher tolerance for the disturbance (Schiedek 1997, Byers 2000) or is an aggressive colonizer of open space (Stachowicz et al. 1999). Recruitment in Chesapeake Bay does not seem to be adversely affected by low DO (Mann \& Rainer 1988, Sagasti et al. 2000), although some organisms such as the solitary ascidian Molgula manhattensis will delay reproduction until after hypoxia has dissipated (Sagasti et al. 2003). Finally, feeding and growth may cease during periods of low DO stress which, in turn, may alter the relative abundance of species present (Breitburg 1992, Diaz \& Rosenburg 1995, Sagasti et al. 2001). In theory, environmental stress can affect assembly dynamics (Belyea \& Lancaster 1999) and general ecological processes (Menge \& Sutherland 1987).

By causing changes in epifaunal community dynamics, low DO pulse events ( $24 \mathrm{~h}$ or less) may enhance success of invasive species. Fox \& Fox (1986) proposed that invasive species may respond according to an environmental gradient, whereby invaders occur more frequently in areas of higher stress due to either greater physiological capacity (such as anaerobic respiration, Schiedek 1997) or reduced competition with native species (Brown et al. 2000). Of course, the timing of recruitment with respect to a low DO event (Llanso 1992) is critical for creating an opportunity for invasion. Disturbance may reduce local, native species diversity by eliminating those species that cannot withstand low DO but favor those invasive species with life history characteristics adapted to the disturbed conditions (Petraitis et al. 1989). In this regard, tolerance to low DO may present an advantage for organisms that have low competitive abilities or low predator avoidance capacity (Marcus 2001). Lower-diversity communities may also be less resistant to invasion (Stachowicz et al. 1999). On the other hand, low DO pulse events might increase species diversity (Sousa 1984) through compensatory mortality of competitive dominants (Connell 1978). By allowing more species to co-exist, the disturbance may create an opportunity for invaders.

Few researchers have explored the relationship between a specific physical variable and the incidence of invasion. An exotic snail (Batillaria attramentaria) in California has greater tolerance for hypoxic conditions than the native snail in the same area (Byers 2000). Stachowicz et al. (2002) discovered a correlation between the percent cover of the invasive tunicate Diplosoma listerianum and winter temperatures in Long Island Sound. The invasion of a bloom-forming dinoflagellate (Prorocentrum minimum) in the Baltic Sea has been associated with increased nitrogen loading (Pertola et al. 2005). The success of the ctenophore Mnemiopsis leidyi in the Black Sea may be related to hypoxia because $M$. leidyi has a high tolerance for low DO (Purcell et al. 2001). Eutrophication and higher global temperatures and precipitation are correlated increasingly with invasion success in terrestrial systems (Dukes \& Mooney 1999).

To test the effects on community structure and susceptibility to invasion, we conducted experiments manipulating exposure to disturbance by low DO on fouling communities of lower Chesapeake Bay, Virginia, USA. We conducted experiments over $2 \mathrm{yr}$ with varying levels and duration of low DO and measured change in species composition and abundance. The epifaunal community served as a good model because of the clear spatial limitation of species abun- 
dance and dominance. Unlike hypoxia field studies that evaluated benthic responses to natural low DO events in Chesapeake Bay (Dauer \& Alden 1995, Dauer et al. 2000), our study included both field and laboratory components to isolate the effects of low DO from other correlated variables such as flow or temperature.

\section{MATERIALS AND METHODS}

Study system: epifaunal community dynamics. Since these experiments were conducted over 2 spring/ summer seasons, it is important to place the experimental results in the context of the seasonal sequence of recruitment patterns. The shallow water fouling community of lower Chesapeake Bay includes a broad range of taxonomic groups including mussels, nudibranchs, barnacles, hydroids, tunicates, amphipods, bryozoans, flatworms, tube worms and errant polychaetes. Barnacles, hydroids and Botryllus schlosseri (colonial tunicate) dominate the spring season recruitment, followed by Molgula manhattensis and spionids in early summer (Otsuka \& Dauer 1982), sabellids and serpulids in mid-summer (Dean \& Hurd 1980, Otsuka $\&$ Dauer 1982), and tunicates and hydroids again in the fall (Dean 1981). Mussels, clams and oysters recruit in the fall and winter (Dean \& Hurd 1980). In the York River, encrusting byrozoans had highest recruitment in late July, and the anemone Diadumene leucolena had highest recruitment in late August (Sagasti et al. 2000). How these recruitment periods coincide with experimental DO manipulations helps to explain the final results.

Study system: native vs. invader status. Botryllus schlosseri, Molgula manhattensis, Ficopomatus enigmaticus and Diadumene lineata Verrill (= Hailplanella luciae) are recognized as invasive or cryptogenic sessile species in Chesapeake Bay (see http://invasions.si.edu/nemesis). The colonial tunicate B. schlosseri was first described in North American Atlantic waters (in Massachusetts Bay) by Couthouy (1838). Greater genetic variability in the B. schlosseri populations in the Mediterranean suggests that it may have originated there (Rinkevich et al. 2001, Stoner et al. 2002). B. schlosseri also settles preferentially on man-made structures in the NW Atlantic, which suggests an introduced status (Stoner et al. 2002, P. Fofonoff pers. comm., G. Lambert pers. comm.). Debate of geographic origin surrounds the solitary tunicate $M$. manhattensis. Its continuous distribution from Maine to Texas and its colonization of both man-made and natural habitats would suggest a NW Atlantic origin, yet it may be conspecific with 3 described British species (Berrill 1950), which would suggest a NE Atlantic origin. The serpulid polychaete $F$. enigmaticus was first documented in Chesapeake Bay in 1994, but was first described in California in 1921 in Lake Merritt, a lagoon off San Francisco Bay (Fauvel 1923). Its likely place of origin is Australia (Allen 1953). In the Mediterranean Sea, F. enigmaticus has the capacity to build calcareous reefs up to $3 \mathrm{~m}$ thick (Fornos et al. 1997), although it has not achieved bioconstructions of this magnitude in the Chesapeake Bay. F. enigmaticus did not recruit to our experimental panels in 2000. The anemone D. lineata was first collected at Cape Charles, Virginia in 1929 (Richards 1931), having been first described on the Atlantic coast in Long Island Sound in 1892 (Verrill 1898).

Although the serpulid Hydroides dianthus is a confirmed native of Chesapeake Bay, it is a recognized opportunist that has invaded other coastal areas around the world. $H$. dianthus has been exported to sites in Western Europe including the British Isles and the Mediterranean Sea, where it has been abundant in harbors and lagoons since 1888 (Zibrowius 1991). $H$. dianthus does not inhabit 'natural' habitats in the Mediterranean, which is some indication of its foreign origins (Zibrowius 1991).

Experimental design. To provide standardized surfaces for fouling community analysis, settling plates were deployed in 2 experiments in the polyhaline zone of lower Chesapeake Bay in the York River subestuary during spring and summer 2000 and 2001. The $14 \times 14$ $\times 0.25 \mathrm{~cm}$ dark grey plastic (PVC) settling plates were sanded to enhance larval settlement, attached to the horizontal bottom surface of a brick, and suspended from a dock approximately $1 \mathrm{~m}$ below mean low water (MLW), a position and orientation that maximizes species richness (Sagasti et al. 2001). Panels were deployed at least $2 \mathrm{~m}$ apart. The horizontal, downfacing position was chosen to limit sediment load and plant growth on the experimental surface. Following deployment in late April, recruitment proceeded undisturbed until late June when the plates were first manipulated. The timing for experimental manipulation was chosen to coincide with the onset of seasonal low DO episodes in the York River subestuary (Haas 1977, Kuo \& Neilson 1987). The plates were deployed in shallow water to avoid exposure to York River hypoxia. Hypoxia predictably develops in the York River periodically (every 2 to 4 wk) every summer (Haas 1977, Kuo \& Neilsen 1987, Sagasti et al. 2001), but remains at depths below $8 \mathrm{~m}$. A YSI minisonde hydrolab was deployed from the dock (Ferry Pier at the Virginia Institute of Marine Science) from July 25 to August 8, 2001 at $1 \mathrm{~m}$ below MLW. During this period, DO never dropped below $4 \mathrm{mg} \mathrm{l}^{-1}$. Daily monitoring of DO at the same site in 2002, from late June to early September, revealed $0 \mathrm{~d}$ of $<4 \mathrm{mg} \mathrm{l}^{-1}$ DO (Jewett 2005). 
The experimental protocol in 2001 and 2000 involved 3 to 5 discrete manipulations over the course of the summer. Each manipulation entailed removing the plates from the river for exposure to varying levels of DO (and varying exposure periods in 2001) in containers, and then replacing them in the river for $2 \mathrm{wk}$ until the next manipulation. Manipulation (see Table 1 for differences between 2001 and 2000 protocols) involved retrieving panels from the York River, photographing them, then placing them in containers in a flow-through water table or in bins with estuarine water that was changed every $2 \mathrm{~h}$ to maintain a consistent temperature across treatments. Unmanipulated controls were photographed and redeployed within $30 \mathrm{~min}$. Over $30 \mathrm{~min}$, DO levels in containers with panels were reduced to $1 \mathrm{mg} \mathrm{l}^{-1}$ for the hypoxia $(\mathrm{H})$ and $3 \mathrm{mg} \mathrm{l}^{-1}$ for the moderately low DO (M) DO treatments with $\mathrm{N}_{2}$ gas. DO level for normoxia $(\mathrm{N})$ treatments was maintained above $5 \mathrm{mg} \mathrm{l}^{-1}$ with constant air-bubbling. For the remainder of the exposure periods, all treatments were bubbled with air only to prevent anoxia. Variable-flow mini water pumps were deployed in treatments to maintain water movement. All DO levels were checked manually with YSI 85 temperature, salinity, DO meters every $30 \mathrm{~min}$ for first $2 \mathrm{~h}$ then every $3 \mathrm{~h}$ thereafter. Treatments were allowed to vary from 0.5 to $2 \mathrm{mg} \mathrm{l}^{-1}$ for $\mathrm{H}$, from 2 to $4 \mathrm{mg} \mathrm{l}^{-1}$ for $\mathrm{M}$, and $>5 \mathrm{mg} \mathrm{l}^{-1}$ for $\mathrm{N}$ (Fig. 1). Airflow was adjusted manually to keep the DO level within these ranges. A third of the water (at appropriate DO level) in each container was changed every $6 \mathrm{~h}$ for the 12 and $24 \mathrm{~h}$ treatments to maintain $\mathrm{pH}$ above and ammonia levels below stress levels. The $\mathrm{pH}$ and ammonia levels were checked randomly before and after water change in 2001. $\mathrm{pH}$ never dropped below 7 and ammonia $\left(\mathrm{NH}_{3}\right)$ remained below $0.055 \mathrm{mg} \mathrm{l}^{-1}$ for all treatments, which is below stress thresholds determined for fishes (Foss et al. 2004). At the completion of the manipulation, the plates were redeployed in the river.

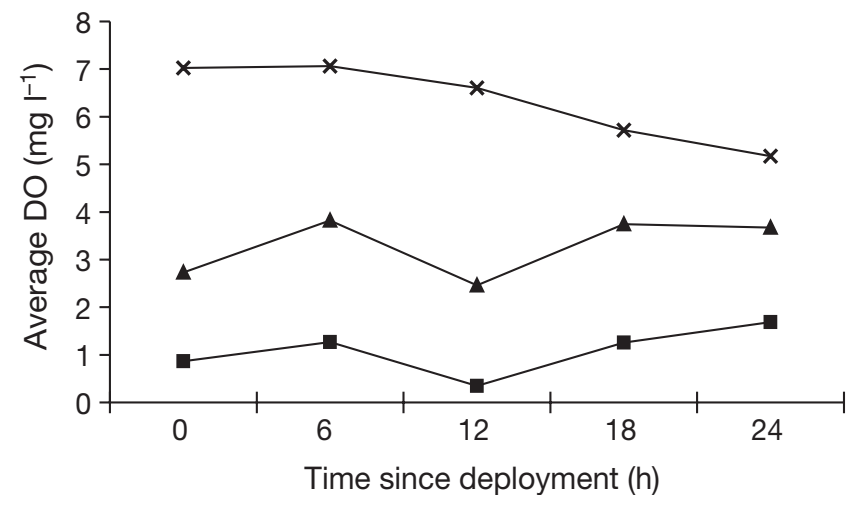

Fig. 1. Average dissolved oxygen (DO) levels experienced by

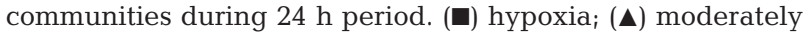
low $\mathrm{DO} ;(\mathrm{x})$ normoxia. $\mathrm{n}=8$

For the 2000 experiment, the random incomplete block design (RIBD), blocked according to the physical proximity of the deployed panels, dictated that the panels be redeployed to the same location after each manipulation. However, the blocking effect was not significant in statistical analysis, so it was dropped in the 2001 experiment which used a completely randomized design (CRD). The lack of a blocking effect suggests (1) recruitment is random when panels are at least $2 \mathrm{~m}$ apart, (2) propagule dispersion may be operating at very small scales and (3) that any other structuring forces were also acting at scales smaller than the block. The CRD design of the 2001 experiment further randomized the effect of larval propagule pressure bias from local, epifaunal sources (from bottom sediments, pier pilings or oyster beds in the vicinity) by randomly assigning the panels to locations after each manipulation.

At the final retrieval, all plates were photographed, and placed in a $0.5 \mathrm{~mm}$ mesh bag which was immersed in $\mathrm{MgCl}$ for 15 to 30 min to relax the organisms, then preserved in $5 \%$ formalin. Biovolume for 2001 panels was measured as the amount of water displaced during immersion (less displacement of the bare panel) when

Table 1. Experimental protocol. H: hypoxia $\left(<2 \mathrm{mg} \mathrm{l}^{-1}\right)$; M: moderately low dissolved oxygen (DO) $\left(2 \mathrm{mg} \mathrm{l}^{-1}<\mathrm{DO}^{2} 4 \mathrm{mg} \mathrm{l}^{-1}\right)$, $\mathrm{N}$ : normoxia (>5 $\mathrm{mg} \mathrm{l}^{-1}$ ); $\mathrm{C}$ : unmanipulated control; $\mathrm{N}$ : total number of manipulations. RIBD: randomized incomplete block design; CRD: completely randomized design. n: no. of replicates

\begin{tabular}{|c|c|c|c|c|c|c|c|c|c|c|}
\hline Year & $\begin{array}{l}\mathrm{n} / \text { total } \\
\text { panels }\end{array}$ & Design & $\begin{array}{l}\text { Manipulation } \\
\text { period:(N) }\end{array}$ & $\begin{array}{c}\text { DO } \\
\text { levels }\end{array}$ & $\begin{array}{l}\text { Exposure } \\
\text { time (h) }\end{array}$ & Set-up & $\begin{array}{l}\text { Water } \\
\text { change }\end{array}$ & Redeployment & Analysis & Biovolume \\
\hline 2001 & $8 / 80$ & CRD & $\begin{array}{c}\text { June 23- } \\
\text { August 9:(3) }\end{array}$ & $\begin{array}{l}\mathrm{H}, \mathrm{M} \\
\mathrm{N}, \mathrm{C}\end{array}$ & $6,12,24$ & $\begin{array}{l}\text { Plate only in } \\
5 \text { l container } \\
\text { in a sea table }\end{array}$ & $\begin{array}{c}\text { Every } \\
6 \mathrm{~h}\end{array}$ & $\begin{array}{l}\text { Random } \\
\text { placement }\end{array}$ & Preserved & Measured \\
\hline 2000 & $7 / 20$ & RIBD & $\begin{array}{c}\text { June 12- } \\
\text { August 23:(5) }\end{array}$ & $\mathrm{H}, \mathrm{N}, \mathrm{C}$ & 24 & $\begin{array}{l}\text { Plate + brick } \\
\text { in } 20 \text { l con- } \\
\text { tainer in sea } \\
\text { table }\end{array}$ & No & $\begin{array}{c}\text { Same location } \\
\text { each time }\end{array}$ & Live & $\begin{array}{c}\text { Not } \\
\text { measured }\end{array}$ \\
\hline
\end{tabular}


transferring plates from formalin to $70 \%$ ethanol, within a month of retrieval.

For species percent cover estimates, a 100-point fixed grid was used and the sessile species occupying the substrate was identified at each point. In addition, all mobile and sessile species present were recorded for a measure of species richness. All organisms were identified to genus and/or species where possible. Sponges, due to difficulty in identification, were kept at phylum level. Questionable identifications were reviewed by trained experts. If distinction between genera or species was untenable, the categories were grouped conservatively before analysis.

In general, mobile fauna were counted only in the total species richness lists. However, the tube-building amphipods Corophium spp. were counted in the percent cover when tubes were present and the organism was found in the tubes (Sebens 1986). Occasionally, the errant polychaete Nereis sp. was also counted in the percent cover if its slime tube was present and an individual was protruding from the tube at the designated point.

The multivariate community response was analyzed using multi-dimensional scaling (MDS), analysis of similarity (ANOSIM) and similarity percent (SIMPER) routines (Plymouth Routines in Multivariate Ecological Research [Primer] software). The ANOSIM randomization test (Clarke \& Green 1988), which is based on the Bray-Curtis similarity index, does not require normal distribution of data to compute R-statistics and significance values. ANOSIM analysis does not test for interaction effects. R-statistics, which reflect resolution between communities, were relatively low for all the analyses, although the associated p-values (level of significance) were significant. Species incidence, as listed in the ANOSIM tables (see Table 2), refers to percent cover of sessile species transformed to presence/absence data. This changed the data from a measure of relative abundance to relative incidence. Cluster analysis results are visually presented in the MDS figures (see Figs. 2 \& 3).

SIMPER was performed on both relative percent cover of organisms and on presence/absence data. SIMPER is a multivariate, exploratory routine that uses the Bray-Curtis similarity index to compare treatments to determine which taxonomic groups are driving community differences. SIMPER does not compute pairwise statistical significance for specific species but it does indicate which species contribute most consistently to differences between communities through the use of standard deviation and dissimilarity (Clarke \& Warwick 2001). SIMPER analysis is reported for only those treatment comparisons which were determined to be significantly different with the ANOSIM routine.
Analysis of variance (ANOVA) was used to determine univariate response of dominant sessile species to treatment. For both multivariate and univariate analyses, percent cover data were arcsine square-roottransformed to meet the assumptions of ANOVA (Sokal \& Rohlf 1995). Pairwise comparisons based on the least-significant difference test (LSD) are reported only when the p-value of the main effect $F$ statistic was below 0.05 to reduce experiment-wise error (Fisher's protected F-test). The Shannon-Wiener $\left(H^{\prime}\right)$ species diversity index, computed on percent cover data (base e), was calculated to compare sessile species diversity between treatments. Species richness is the number of distinct species or genera. Correlation analysis was performed to explore the relationship between cover of certain species and overall diversity $\left(H^{\prime}\right)$.

\section{RESULTS}

\section{Epifaunal community response to low DO}

In both 2001 and 2000, periodic exposure to hypoxia caused changes in community composition (Table 2). In 2001, exposure to hypoxic conditions for as little as $6 \mathrm{~h}$ every $2 \mathrm{wk}$ led to changes in the percent cover of species (Fig. 2). Exposure to hypoxic conditions for $12 \mathrm{~h}$ led to change in the composition (presence/ absence) of species (Fig. 3). In other words, species replacement did not occur until the community was exposed to hypoxia $\left(<2 \mathrm{mg} \mathrm{l}^{-1} \mathrm{DO}\right)$ for at least $12 \mathrm{~h}$.

Periodic hypoxia $\left(<2 \mathrm{mg} \mathrm{l}^{-1}\right)$ led to an increase in Hydroides dianthus cover (Figs. 4 \& 5) relative to the control plates in 2001 and 2000. The difference in cover of $H$. dianthus between the $\mathrm{H}$ and $\mathrm{N}$ treatments was statistically significant in 2001, but not in 2000 (Table 3). H. dianthus experienced highest recruitment in July and August which might explain its success since the DO manipulations occurred throughout both months. Sagasti et al. (2001) showed H. dianthus to have a high tolerance for low DO, with mortality at $1 \mathrm{mg} \mathrm{l}^{-1}$ DO during $5 \mathrm{~d}$ at $0 \%$.

In 2001, there was an inverse relationship between total barnacle (Balanus eburneus plus B. improvisus) and Hydroides dianthus cover (Fig. 6). This correlation analysis included all settling panels regardless of treatment. $H$. dianthus had the highest percent cover in the hypoxia-treated communities at $22 \%$ and the lowest in the normoxia communities at $11 \%$ (Fig. 4).

When barnacles or tube-dwelling serpulids occupied space at high enough densities, they prevented other species from settling. As barnacle cover increased, sessile species diversity $\left(H^{\prime}\right)$ increased until approximately $15 \%$ barnacle cover was reached, after which $H^{\prime}$ decreased (Fig. 7). Hydroides dianthus had greater 
Table 2. ANOSIM (analysis of similarity) results comparing assemblages on panels as a function of DO treatment for 2001 and 2000 data. Abbreviations as in Table 1; significant $p$ values in boldface

\begin{tabular}{|c|c|c|c|c|c|c|c|c|}
\hline \multirow{3}{*}{2001} & \multirow{3}{*}{ Global R } & \multirow{2}{*}{\multicolumn{3}{|c|}{$\begin{array}{l}\text { - DO treatment }(\mathrm{n}=18) \\
\text { Pairwise comparison }\end{array}$}} & \multirow{3}{*}{$\overline{\text { Global R }}$} & \multirow{2}{*}{\multicolumn{3}{|c|}{$\begin{array}{l}\text { Exposure time }(\mathrm{n}=18) \\
\text { Pairwise comparison }\end{array}$}} \\
\hline & & & & & & & & \\
\hline & & $\mathrm{H}$ vs. $\mathrm{M}$ & H vs. $\mathrm{N}$ & M vs. $\mathrm{N}$ & & 6 vs. $12 \mathrm{~h}$ & 6 vs. $24 \mathrm{~h}$ & 12 vs. $24 \mathrm{~h}$ \\
\hline \multicolumn{9}{|c|}{ Primary cover } \\
\hline $\mathrm{R}$ & 0.15 & 0.21 & 0.23 & 0.04 & 0.06 & & & \\
\hline $\mathrm{p}$ & $<0.002$ & $<0.004$ & $<0.004$ & 0.260 & 0.110 & & & \\
\hline \multicolumn{9}{|c|}{ Species Incidence } \\
\hline $\mathrm{R}$ & 0.10 & 0.17 & 0.12 & 0.02 & 0.08 & 0.15 & 0.03 & 0.07 \\
\hline $\mathrm{p}$ & $<0.02$ & $<0.006$ & $<0.040$ & 0.320 & 0.040 & $<0.020$ & 0.370 & 0.150 \\
\hline \multirow[t]{2}{*}{2000} & Global R & \multicolumn{3}{|c|}{ Pairwise comparison } & & & & \\
\hline & $(\mathrm{n}=7)$ & H vs. $\mathrm{N}$ & H vs. C & N vs. C & & & & \\
\hline \multicolumn{9}{|c|}{ Primary cover } \\
\hline $\mathrm{R}$ & 0.36 & 0.33 & 0.61 & 0.06 & & & & \\
\hline $\mathrm{p}$ & 0.001 & 0.003 & 0.001 & 0.240 & & & & \\
\hline \multicolumn{9}{|c|}{ Species incidience } \\
\hline $\mathrm{R}$ & 0.13 & 0.27 & 0.09 & 0.04 & & & & \\
\hline $\mathrm{p}$ & 0.052 & 0.010 & 0.180 & 0.310 & & & & \\
\hline
\end{tabular}

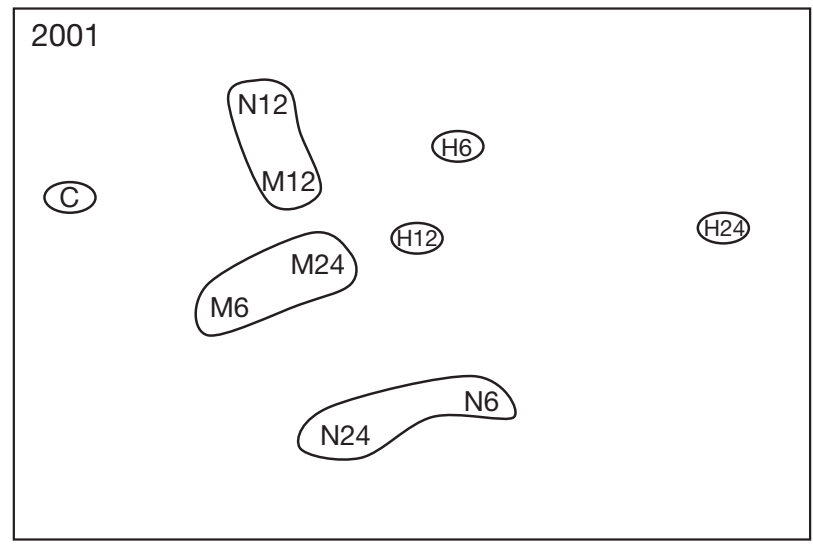

Fig. 2. Results of multi-dimensional scaling (MDS) analysis of arcsine square-root-transformed percent cover data for sessile species, averaged by treatment for 2001 experiment. Treatments grouped at $85 \%$ similarity level (cluster analysis) are encircled. Letters represent DO treatment (H: hypoxia, $\mathrm{M}$ : moderately low DO, N: normoxia, C: unmanipulated control); numbers represent exposure time (h). Stress $=0.07$

overall cover in 2000, perhaps due to the longer duration of this experiment (Table 1), and its effect on settlement of other sessile species was similar to the effect of barnacles in 2001 (Fig. 8).

Balanus eburneus, Hydroides dianthus and Demonax microphthalma accounted for $60 \%$ of the similarity between treatments. However, the shifting relative percent cover of $B$. eburneus and $H$. dianthus also accounted for the greatest percent dissimilarity

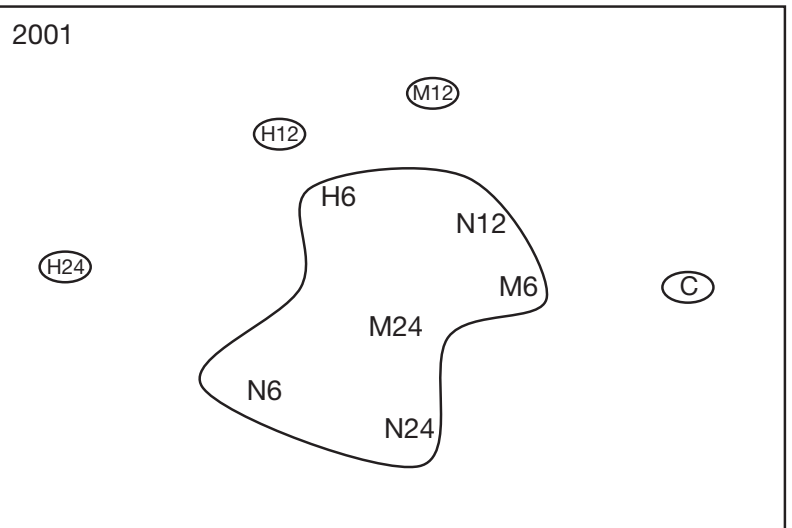

Fig. 3. Results of multi-dimensional scaling (MDS) analysis of presence/absence transformed data for sessile species, averaged by treatment for 2001 experiment. Stress $=0.08$; further details as in Fig. 2 legend

between the treatments (Table 4). Of the total dissimilarity between any of the paired treatment comparisons, 12 to $13.4 \%$ was due to B. eburneus cover, with higher cover always in the relatively higher DO treatments (Table 4). H. dianthus cover contributed 8 to $9 \%$ of the dissimilarity between treatments.

Beyond the 5 dominant species (serpulid Hydroides dianthus, solitary tunicate Molgula manhattensis, colonial tunicate Botryllus schlosseri, barnacle Balanus eburneus and sabellid Demonax microphthalma), differences between communities were due also to small 


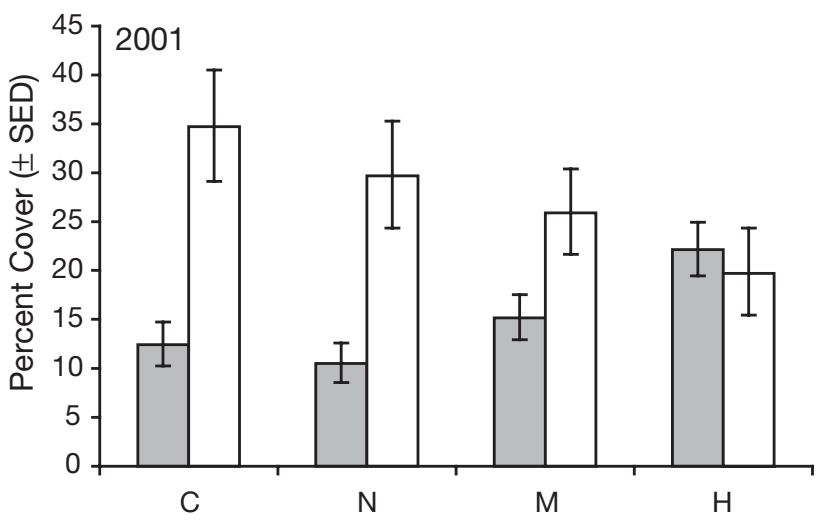

Fig. 4. Balanus eburneus plus B. improvisus (open bars) and Hydroides dianthus (grey bars). Percent cover as a function of treatment in 2001 experiment. Abbreviations as in Fig. 2. See Table 3 for statistical differences among treatments; $\mathrm{n}=18$. $\mathrm{SED}=$ standard error of difference

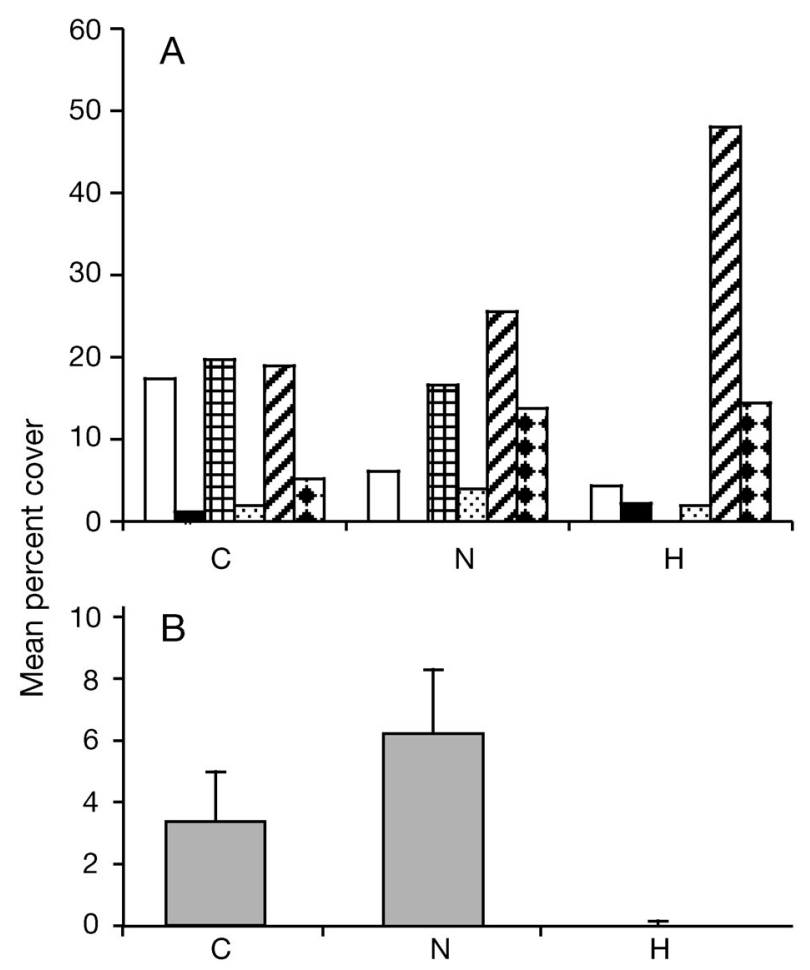

Fig. 5. Species cover as a function of treatment in 2000 experiment. (A) Barnacles (open bars); encrusting bryozoans (solid bars); Demonax mocrophthalma (crosshatched bars); Diadumene leucolena (stippled bars); Hydroides dianthus (striped bars); Molgula manhattensis (diamond bars). (B) Botryllus schlosseri; bars represent standard error of mean difference

(SED). Abbreviations as in Fig. 2

changes in cover of many species. Bryozoans, in general, tended to settle on unoccupied space, but also grew over live and dead barnacles and occasionally up the stolons of hydroids. The cover of 2 encrusting bryozoan species, Membranipora tenuis and Conopeum

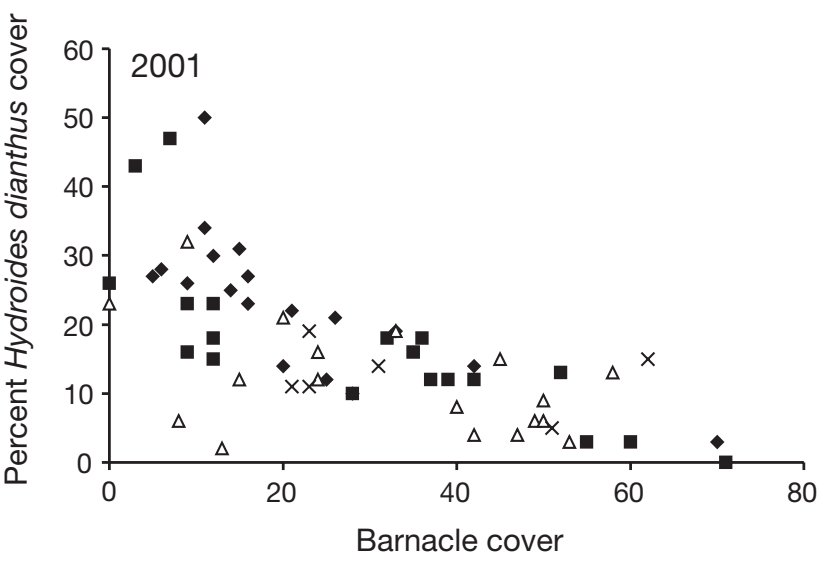

Fig. 6. Percent cover of Hydroides dianthus vs. cover of Balanus eburneus and B. improvisus combined in 2001. Correlation analysis: $r=-0.72, p<0.0001(n=60)$, computed on all data regardless of treatment. ( ) Hypoxia; ( $\square$ ) moderately low DO; $(\Delta)$ normoxia; $(\times)$ unmanipulated control

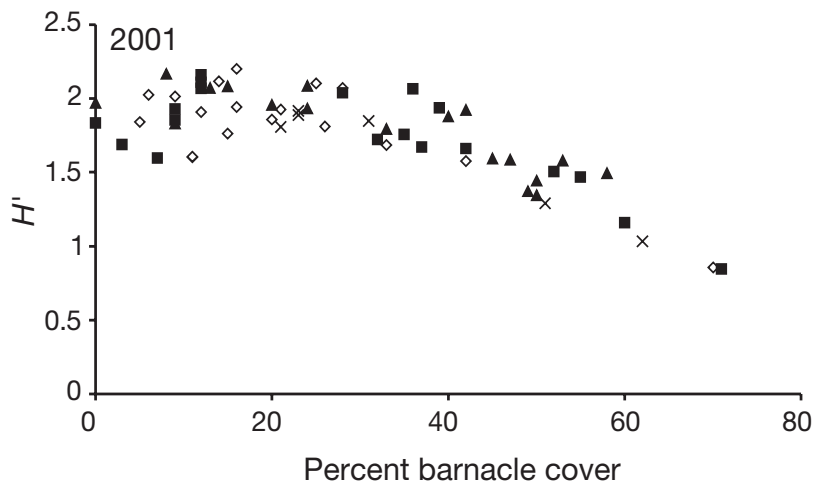

Fig. 7. $H^{\prime}$ (Shannon-Wiener index) vs. barnacle cover (Balanus eburneus and B. improvisus combined) for 2001. Correlation analysis: $\mathrm{r}=-0.78, \mathrm{p}<0.0001$. $(\diamond)$ Hypoxia; $(\boldsymbol{\square})$ moderately low DO; $(\boldsymbol{\Delta})$ normoxia; $(\times)$ unmanipulated control

chesapekensis, combined accounted for 12.6 to $15 \%$ of the differences between the hypoxia $(\mathrm{H})$ and the other treatments (Table 4). C. chesapekensis contributed most consistently to the differences between the hypoxia and control (C) multivariate comparison, with greater average cover on the $\mathrm{H}$ panels. The hydroid Halopteris tenella and the anemone Diadumene leucolena consistently contributed most to the differences between treatments ( $\mathrm{H}$ vs. $\mathrm{N}, \mathrm{H}$ vs. C respectively) according to species incidence. $H$. tenella, on average, had highest incidence on the $\mathrm{N}$ panels and $D$. leucolena had highest incidence on the $\mathrm{H}$ panels (SIMPER does not assign significance to these differences) (Table 4).

The total percent cover of combined bare space, dead barnacles and empty sand or sediment tubes was highest for the $24 \mathrm{~h}$ manipulations averaged across DO 


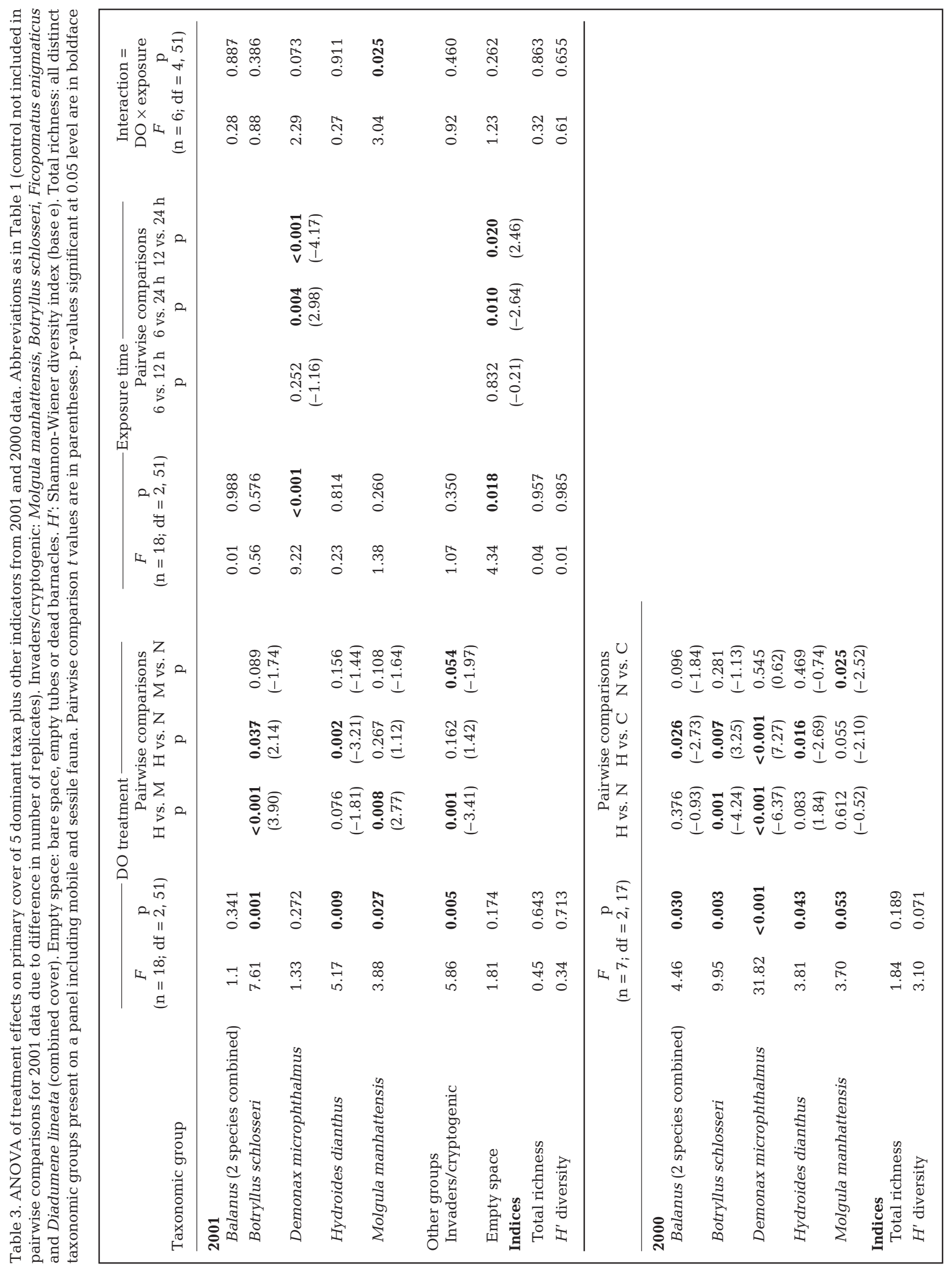




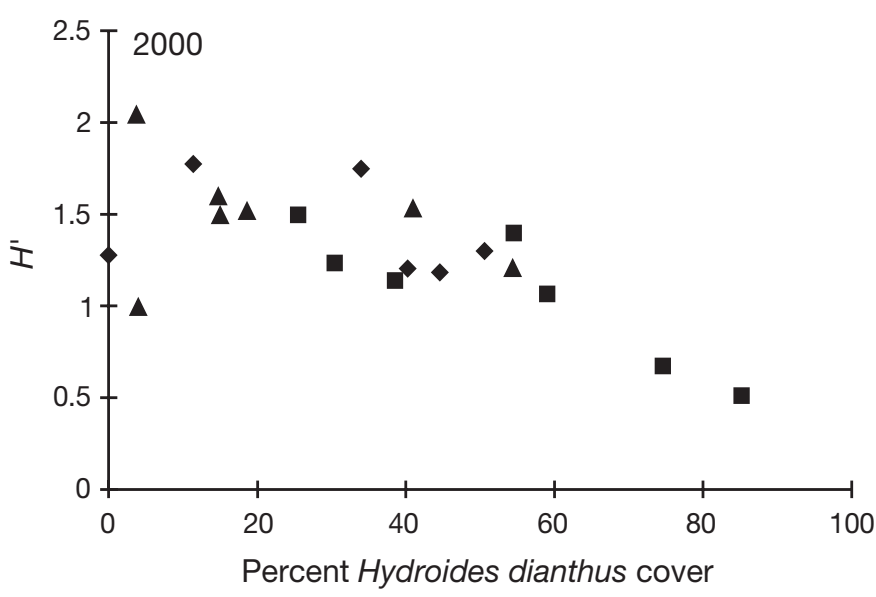

Fig. 8. $H^{\prime}$ of sessile species (Shannon-Wiener Index) vs. Hydroides dianthus cover for 2000. Correlation analysis: $\mathrm{r}=$ $-0.67, \mathrm{p}<0.01$. Correlation computed on all data regardless of treatment $(\mathrm{n}=20)$. ( $\mathbf{\square})$ Hypoxia; $(\bullet)$ normoxia; $(\boldsymbol{\Delta})$ unmanipulated control

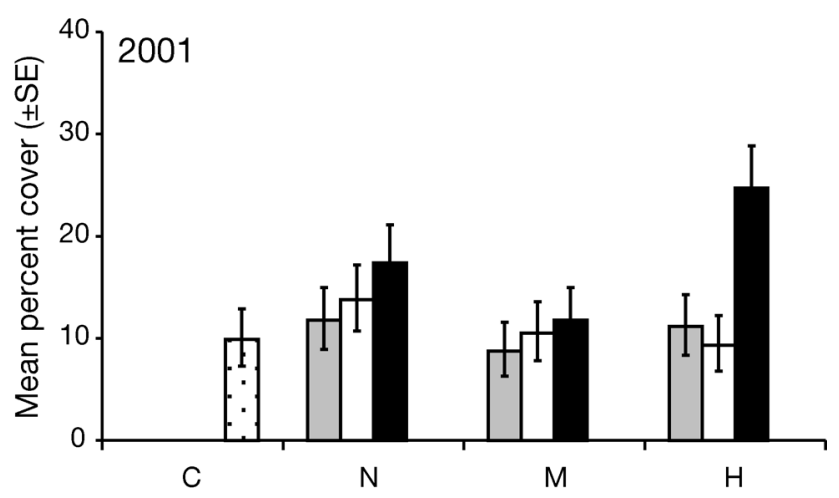

Fig. 9. Mean empty space (i.e. bare space, vacated tubes or dead barnacles) in 2001. Exposure times were $6 \mathrm{~h}$ (grey bars), $12 \mathrm{~h}$ (open bars) and $24 \mathrm{~h}$ (black bars). See Table 3 for ANOVA analysis; $\mathrm{n}=6$. Abbreviations as in Fig. 2

treatments. All plates exposed for $24 \mathrm{~h}$ had $>15 \%$ mean unoccupied space compared with $11 \%$ for the 6 and $12 \mathrm{~h}$ exposure treatments (Table 3). The H24 treated plates exhibited the most difference (Fig. 9) with a mean cover of $24 \%$ dead or bare space.

The biovolume of the epifaunal communities was lowest in the hypoxia-treated panels and highest for the unmanipulated control in $2001 \mathrm{df}=70$, Student's $t=-2.56, \mathrm{p}=0.01)$. No significant difference existed among the $\mathrm{H}, \mathrm{M}$ and $\mathrm{N}$ treatments (Fig. 10). The diversity on the panels without regard to treatment varied inversely with biovolume (Fig. 11), which was probably related to the corresponding dominance of barnacles as biovolume increased.

Mobile species were recorded during the general survey of species richness for each panel. Composition

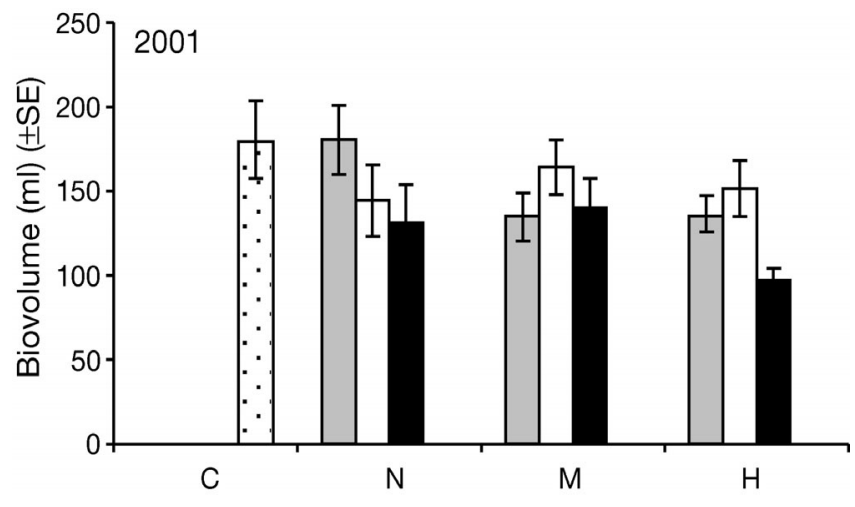

Fig. 10. Mean biovolume as a function of treatment in 2001, where biovolume represents amount of water displaced by community assemblages on a panel. See Table 3 for ANOVA analysis; $\mathrm{n}=8$. Further details as in Fig. 9 legend

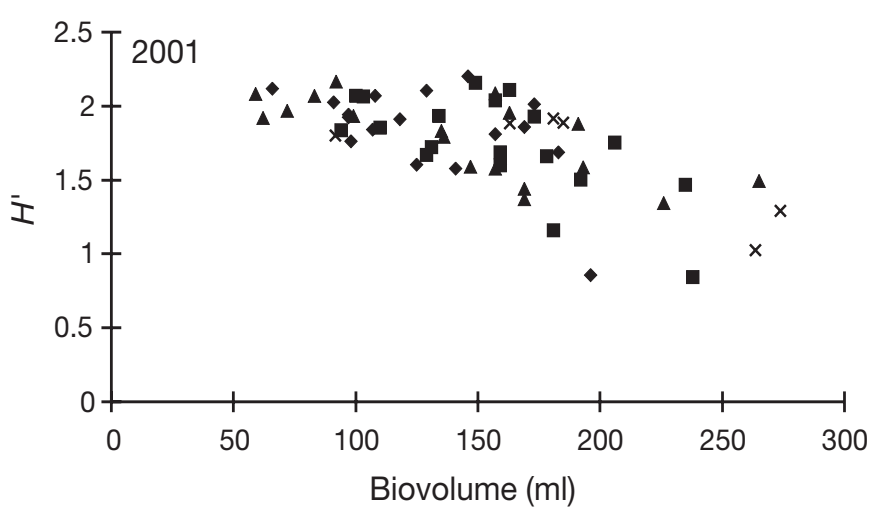

Fig. 11. $H^{\prime}$ on panels (Shannon-Wiener Index) vs. biovolume for 2001. Correlation analysis: $r=-0.63, p<0.001$. Correlation computed on all data regardless of treatment $(\mathrm{n}=60)$.

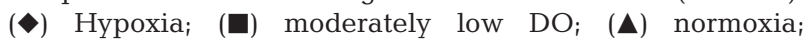
$(\times)$ unmanipulated control

of mobile taxa did not differ by treatment (ANOSIM, Global $R=-0.06, p=0.90$ ). Some taxa, such as caprellids and flatworms, were either dead or congregated at the surface of the water in the tanks at the end of the $\mathrm{H}$ manipulations.

In the 2001 experiment, diversity as measured by univariate indices (Richness, Shannon-Wiener) did not vary by treatment for either the sessile or the mobile epifauna (Table 3). However, the ANOSIM analysis (Table 2) and the multivariate SIMPER analysis (Table 4) indicate that the composition of species did change according to exposure to low DO. Diversity measures such as $H^{\prime}$ and $\mathrm{R}$, which cannot take into account the changing composition of the communities, are less helpful for assessing the impact of environmental conditions (Drake et al. 1999). 


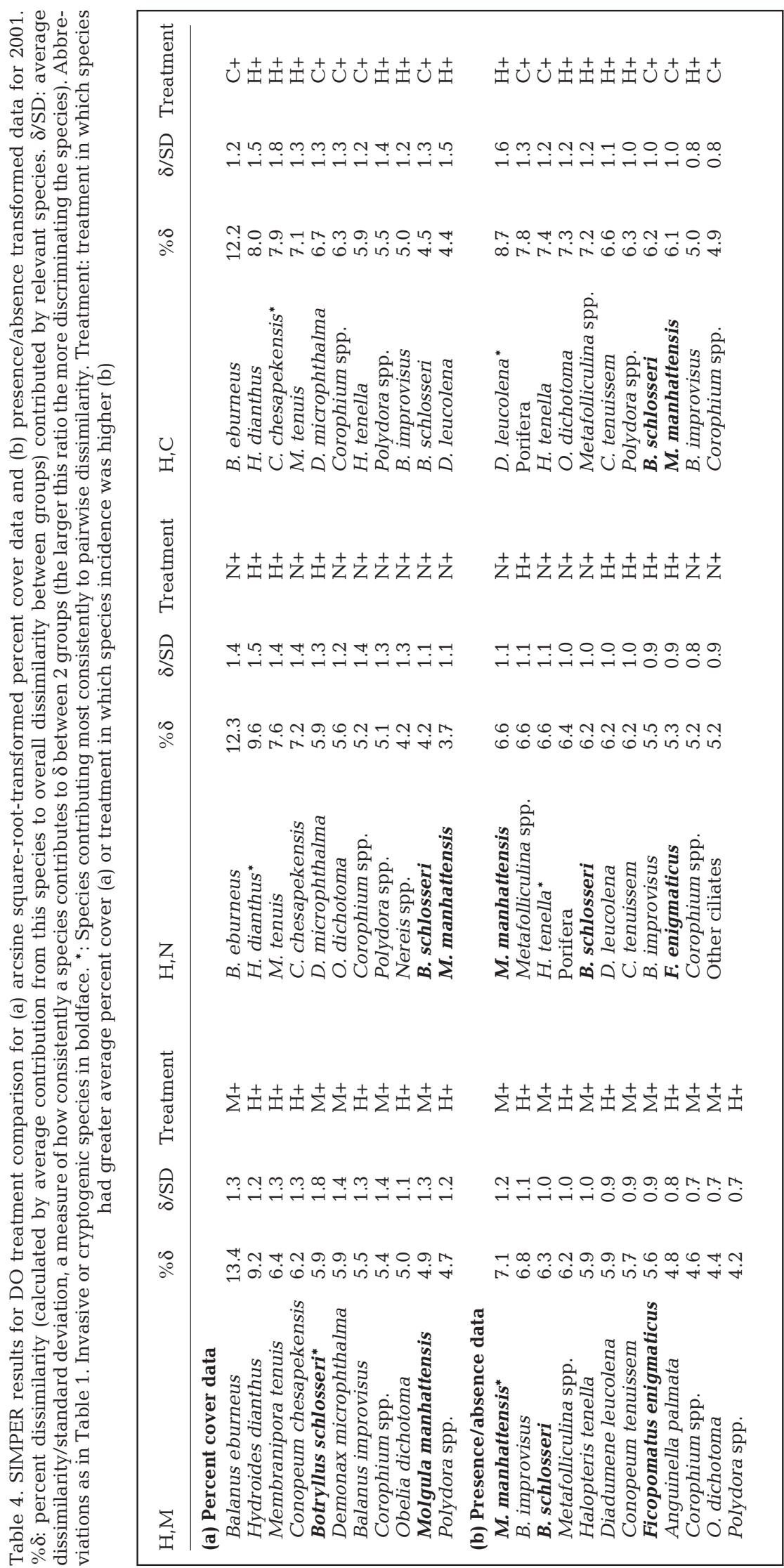

\section{Invader response to low DO}

Although the space occupation of known invasive and cryptogenic species was low $(<5 \%)$ compared with the rest of the community, their response clearly differed significantly among treatments in the 2001 experiment (Table 3). The combined cover of the 4 known invader and cryptogenic sessile organisms was highest on the moderately low DO (M)-exposed panels (Fig. 12). The cover did not differ between the normoxia $(\mathrm{N})$ and hypoxia $(\mathrm{H})$ treatments, but both differed from cover in the $M$ treatments (Table 3). Molgula manhattensis and Botryllus schlosseri were mainly driving this difference. Both species had highest cover $(4 \%)$ on the M-exposed panels and lowest cover on the $\mathrm{H}$ exposed panels $(<0.5 \%)$. In the 2000 experiment, B. schlosseri's average cover $(0 \%)$ in Treatment $\mathrm{H}$ was significantly lower than its cover $(6 \%)$ in $\mathrm{N}$. However, in 2000, M. manhattensis had increased cover in both manipulated treatments ( $\mathrm{H}$ and $\mathrm{N}$ ) vs. the natural control (C) (Fig. 5, Table 3).

\section{DISCUSSION}

Extensive reviews of hypoxia and its effects on mobile and sessile fauna (Diaz \& Rosenberg 1995, Gray et al. 2002) overlook the shallow, seasonal DO depletions that occur in localized areas (Sanford et al. 1990). In 1999, Jewett (2005) documented a low DO event in Baltimore Harbor which extended in some sites to the surface with DO levels below $2 \mathrm{mg} \mathrm{l}^{-1}$ at $1 \mathrm{~m}$ depth at midday. Jewett (2005) also surveyed DO in 8 sites in lower Chesapeake Bay in 2002, 4 of which experienced periods of moderately low DO (<4 $\mathrm{mg} \mathrm{l}^{-1}$ ) lasting from hours to weeks. The spatial scale of hypoxic bottom waters has been extensively mapped, both in the Chesapeake Bay and estuaries worldwide, but the spatial and temporal scale of moderately low DO in shallow areas is not well understood. 


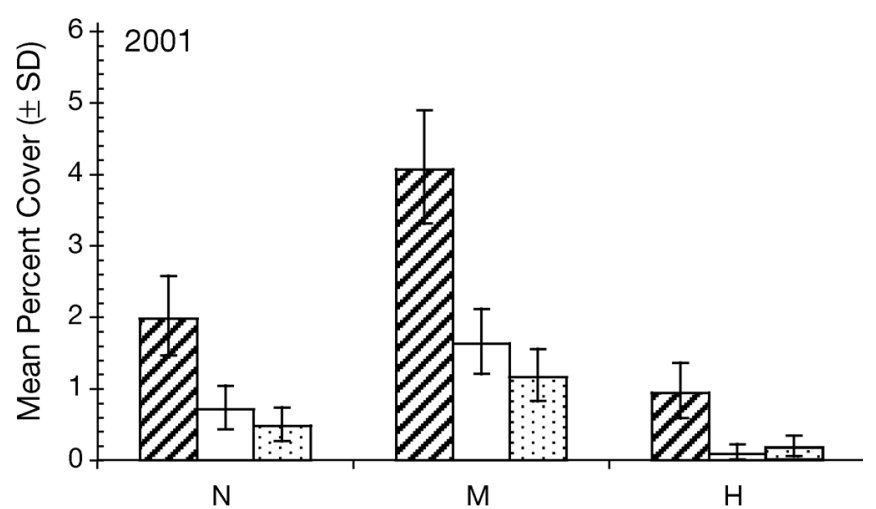

Fig. 12. Invader/cryptogenic species cover as a function of treatment in 2001. Hatched bars show total cover of invader/cryptogenic species, comprising Botryllus schlosseri (open bars), Molgula manhattensis (stippled bars), Diadumene lineata and Ficopomatus enigmaticus. See Table 3 for ANOVA analysis; $\mathrm{n}=18$. Abbreviations as in Fig. 2

Moderately low DO may represent a refuge for some species as exhibited by the relative increase in cover of invasive/cryptogenic species (Fig. 12). Exposure to hypoxia did not facilitate invasion success. All 4 known invasive and cryptogenic species had lowest percent cover on the hypoxia $(\mathrm{H})$ treated plates in 2000 and 2001 (Figs. 5 \& 12). However, periodic exposure to moderately low DO $\left(2 \mathrm{mg} \mathrm{l}^{-1}<\mathrm{DO}<4 \mathrm{mg} \mathrm{l}^{-1}\right)$ led to an increase in invasive/cryptogenic species cover (Fig. 12). If the intermediate disturbance effect were responsible (Connell 1978, Petraitis et al. 1989), one would expect species diversity to be higher in the $M$ treatments; but neither $H^{\prime}$ nor richness differed significantly as a function of treatment (Table 3). Laine (2003) concluded that declining richness due to low DO stress in the Baltic Sea may make that system more vulnerable to invasion, but richness alone did not correlate with invasion success in the present experiment.

Hypoxia has the ability to cause local mortality, to shift dominance (thus changing species diversity) and/or to serve as a refuge for less dominant members of the community. Species-specific local mortality could occur if DO levels dropped below $2 \mathrm{mg} \mathrm{l}^{-1}$ for a minimum of $6 \mathrm{~h}$, given that the composition of species changed across DO treatments (Table 2) and that the percent cover of at least 2 dominant species, Demonax microphthalma and Botryllus schlosseri, was either reduced or nonexistent on the hypoxia-exposed panels (Fig. 5). Hypoxia also caused shifts in the dominant species, as shown by the reduction in D. microphthalma (Fig. 5) and Balanus spp. cover and the increase in Hydroides dianthus cover (Fig. 4) which, in turn, was correlated with changes in species diversity (Figs. $7 \&$ 8), depending on the extent of the $H$. dianthus or barnacle cover.
The dynamics of recovery after hypoxic or anoxic events has been described by the Pearson \& Rosenberg (1978) organic enrichment model (Heip 1995, Powilleit \& Kube 1999). The model is based on changes in species number, abundance and biomass (SAB) as the effect of organic enrichment diminishes spatially from a central source. Pearson \& Rosenberg (1978) and Heip (1995) suggest that the model could also be applied to time elapsed since an hypoxic disturbance, with smallbodied, opportunistic species dominating recruitment following a low DO event. In our experiment, communities exposed to hypoxia for $24 \mathrm{~h}$ (the highest level of disturbance in this study) exhibited a reduction in biovolume (Fig. 10), and the opportunistic polychaete Hydroides dianthus increased in the $\mathrm{H}$ treatments (Figs. 4 \& 5). Other studies in Chesapeake Bay (Dauer \& Alden 1995), in Kattegat (Hagerman et al. 1996), in Norwegian fjords (Mirza \& Gray 1981) and in the Gulf of Mexico (Rabalais et al. 1991) have documented the increasing dominance of opportunistic species in response to degraded conditions. From 1985 to 1991, the percent of total biomass in the central Chesapeake Bay composed of opportunistic species increased as DO conditions worsened (Dauer \& Alden 1995).

Timing of exposure to disturbance can determine community differences (Nandakumar 1996). The timing of the low DO manipulations, from mid-June through August (when low DO disturbance occurs in the bay), probably affected which species benefited. Since peak recruitment of Hydroides dianthus is in July and August (Dean \& Hurd 1980, Otsuka \& Dauer 1982) and the adults have a tolerance for low DO (Sagasti et al. 2001), the increase in H. dianthus cover was predictable. $H$. dianthus may take advantage of space-clearing disturbance, because its recruitment is inhibited by most other sessile species (Dean \& Hurd 1980) and it preferentially settles on bare space (Dean 1981). In addition, $H$. dianthus larvae tend to settle near other conspecific adults (Toonen \& Pawlik 2001), so its response to cleared space is amplified. Finally, $H$. dianthus larvae are planktonic for up to $2 \mathrm{wk}$ (Toonen \& Pawlik 2001), as compared to $<1$ d for most tunicates, so it can travel greater distances to find bare space created by low DO disturbance. Serpulids, in general, are considered good colonizers and poor competitors (Dunstan \& Johnson 2004). Research after a severe hypoxic event in the Baltic Sea also concluded that timing of the event affected pool of larval recruits and thus community composition (Powilleit \& Kube 1999).

In 2001 and 2000, Balanus spp. experienced heightened mortality mid-summer in the low DO treatments after strong recruitment in the spring. Balanus spp. larvae were available throughout the summer, although low DO may have hindered recruitment of 
settled cyprids. Otsuka \& Dauer (1982) attributed barnacle mortality to predation by the flatworm Stylochus ellipticus. However, S. ellipticus has a low tolerance for DO stress. In laboratory experiments, S. ellipticus experienced $59 \%$ mortality when exposed to hypoxia (1 $\mathrm{mg} \mathrm{l}^{-1} \mathrm{DO}$ ) for $5 \mathrm{~d}$ (Sagasti et al. 2001). It is possible that, in the estuary, these flatworms experience high mortality during hypoxic periods, so that their predation on barnacles during such periods would decrease. However, predation on stressed barnacles after redeployment may account for increased vulnerability. Fishes and crabs in the York River prey on stressed organisms, such as barnacles, upon redeployment (Nestlerode \& Diaz 1998). Mud crabs, S. ellipticus and blue crabs all prey on barnacles. It would take some time for mud crabs and $S$. ellipticus to recruit to the stressed settling panels, but very mobile fishes and blue crabs might have had an immediate impact. In natural conditions, predators have been reported to return to affected areas before prey has recovered (Nestlerode \& Diaz 1998).

Other species had positive responses to low DO, including the anemone Diadumene leucolena and 2 encrusting bryozoans. D. leucolena experienced a recruitment pulse in late July, which may account for its (on average) higher incidence on the Treatment $\mathrm{H}$ panels (Table 4). It may also have a high tolerance for low DO given that cnidarians are found in low DO conditions worldwide (Purcell et al. 2001). Reduced predation may account for the higher cover and incidence of Membranipora tenuis and Conopeum chesapekensis on the $\mathrm{H}$ panels (Table 4). Predation on encrusting bryozoans on the disturbed panels may have been reduced, since the nudibranch Doridella obscura, which grazes on bryozoans, has a low tolerance for hypoxia (Sagasti et al. 2001).

The mechanism facilitating increased cover of invasive/cryptogenic species in the moderately low DO treatments was probably multi-factorial. These invasive/cryptogenic species were clearly sensitive to hypoxic conditions, yet they also must have had some tolerance to lower DO conditions. They may also have had the capacity to capitalize on open space by increasing sexual and/or asexual reproduction during stressful conditions when predation by barnacles and other filter-feeders was reduced. The stress of the low DO manipulation may have induced spawning in Molgula manhattensis (R. Osman pers. comm.). Because $M$. manhattensis has a short larval stage (<1 d) (Costello et al. 1957) and its tadpole larvae have been shown to settle near spawning adults (Graham \& Sebens 1996), it might capitalize on local patch clearings near resident adults. However, in laboratory experiments (Sagasti et al. 2001), M. manhattensis adults delayed reproduction and the larvae delayed settlement until after the hypoxia period. Botryllus schlosseri adult tolerance for periodic hypoxia was low (Figs. 5 \& 12), and this species was not found in deep waters where periodic hypoxia occurred (Sagasti et al. 2000). Tunicates in general are better competitors than colonizers (Dunstan \& Johnson 2004), so the increased percent cover of these tunicates in moderately low DO may also have resulted from overgrowing other lesscompetitive, less low-DO-tolerant sessile species such as sponges and barnacles.

Ficopomatus enigmaticus, a recent arrival to the Chesapeake Bay, also had higher cover in communities subjected to moderately low DO. However, tunicates and serpulids probably succeed for different reasons. This invasive serpulid was observed settled on and around Hydroides dianthus. It may cue settlement on $H$. dianthus adults or at least prefer similar conditions. F. enigmaticus has a high tolerance for low DO and tolerates a broad salinity range (Fornos et al. 1997).

How the geographic area affected by a low DO disturbance compares to the colonizing capacity of the resident species will determine changes in local species diversity (Sousa 1984). The scale of a disturbance event can determine the speed of recovery in soft sediment communities (Gamenick et al. 1996). However, if the frequency of low DO episodes is low, then regional species richness will be maintained because competitive species, such as some colonial tunicates and sponges, will not be eliminated (Miller 1982). Temporary low DO in shallow areas differs fundamentally from hypoxia in deep zones of the Bay which can last for months. The patchiness of disturbance by low DO in shallow waters may lead to a mosaic of environments; some dominated by Hydroides dianthus, others by Balanus eburneus and still others by a more heterogeneous community depending on the severity, frequency and geographic extent of the low DO episodes.

In conclusion, our experiments illustrated how composition of species in local areas may change with increased stress from low DO. Certain species, such as Hydroides dianthus, dominated the stressed communities, leading to local aggregations that, in turn, reduced the incidence and cover of other species. The DO stress directly reduced the cover of non-tolerant species such as Demonax microphthalma. Invasive species benefited from moderately low DO, a condition prevalent in nearshore areas. The opportunity for recruitment and spread of invasive species may be facilitated by low DO disturbance. Low DO pockets may enhance overall survival of invasive species by providing source populations for the region. High temperatures are correlated with low DO conditions worldwide, which may make marine and estuarine systems more vulnerable to invasion as global temperatures rise due to climate change. 
It may be possible to use a sample of the epifaunal community to gauge the health of the local waters. Many studies have documented a predominance of opportunistic species and a decline in species richness in areas exposed to hypoxia (Heip 1995, Hagerman et al. 1996, Laine 2003). D. M. Dauer et al. (pers. comm.) proposed that overabundance of certain taxa may reflect degraded environmental conditions. In the Chesapeake Bay, the existence of extensive Hydroides dianthus aggregations probably is an indicator of stressful local conditions. In addition, greater percent cover of invasive/cryptogenic species may indicate that stressful but not lethal episodes of hypoxia have occurred.

Acknowledgements. The following people deserve special mention for advice on experimental design, loan of laboratory space or assistance in doing the experiments: K. Sebens, R. Osman, A. Sagasti, J. Crooks, L. McCann, L. Schaffner, M. Seebo, J. Blum, J. Kurtin, J. van Montfrans, A. Key, T. Gurley, G. Smith, J. Lawshe and M. Kramer. This work was made possible through the generous funding of the Smithsonian Institution and a University of Maryland Chesapeake Bay Summer Grant. E.B.J. especially thanks the Virginia Institute of Marine Science for allowing me to perform these experiments at their facility.

\section{LITERATURE CITED}

Allen FE (1953) Distribution of marine invertebrates by ships. Aust J Mar Freshw Res 4:307-316

Belyea LR, Lancaster J (1999) Assembly rules within a contingent ecology. Oikos 86:402

Berrill NJ (1950) The Tunicata, with an account of the British species. Quadritch, London

Brante A, Hughes RN (2001) Effect of hypoxia on the prehandling behaviour of Carcinus maenas feeding on Mytilus edulis. Mar Ecol Prog Ser 209:301-305

Breitburg DL (1990) Near-shore hypoxia in the Chesapeake Bay: patterns and relationships among physical factors. Estuar Coast Shelf Sci 30:593-609

Breitburg DL (1992) Episodic hypoxia in Chesapeake Bay: interacting effects of recruitment, behavior, and physical disturbance. Ecol Monogr 62:525-546

Brown CJ, Albuquerque RM, Cragg SM, Eaton RA (2000) Effects of CCA (copper chrome-arsenic) preservative treatment of wood on settlement and recruitment of barnacles and tube building polychaete worms. Biofouling 15:151-164

Byers JA (2000) Differential susceptibility to hypoxia aids estuarine invasion. Mar Ecol Prog Ser 203:123-132

Clarke KR, Green RH (1988) Statistical design and analysis for 'biological effects' study. Mar Ecol Prog Ser 46:213-226

Clarke KR, Warwick RM (2001) Change in marine communities: an approach to statistical analysis and interpretation. Plymouth Marine Laboratory, Plymouth

Connell JH (1978) Diversity in tropical rain forests and coral reefs. Science 199:1302-1310

Costello DP, Davidson ME, Eggers A, Fox MH, Henley C (1957) Methods for obtaining and handling marine eggs and embryos. Lancaster Press, Lancaster, PA

Couthouy JP (1838) Descriptions of new species of Mollusca and shells, and remarks on several polypi found in Massa- chusetts Bay. Boston J Nat Hist 2:53-111

Dauer DM, Alden RW (1995) Long-term trends in the macrobenthos and water quality of the lower Chesapeake Bay (1985-1991). Mar Pollut Bull 30:840-850

Dauer DM, Weisberg SB, Ranasinghe JA (2000) Relationships between benthic community condition, water quality, sediment quality, nutrient loads, and land use patterns in the Chesapeake Bay. Estuaries 23:80-96

Dean TA (1981) Structural aspects of sessile invertebrates as organizing forces in an estuarine fouling community. J Exp Mar Biol Ecol 53:163-181

Dean TA, Hurd LE (1980) Development in an estuarine fouling community: the influence of early colonists on later arrivals. Oecologia 46:295-301

Decker MB, Breitburg DL, Purcell JE (2004) Effects of low dissolved oxygen on zooplankton predation by the ctenophore Mnemiopsis leidyi. Mar Ecol Prog Ser 280: 163-172

Diaz RJ (2001) Overview of hypoxia around the world. J Environ Qual 30:275-281

Diaz RJ, Rosenberg R (1995) Marine benthic hypoxia: a review of its ecological effects and the behavioral responses of benthic macrofauna. Oceanogr Mar Biol Annu Rev 33:245-303

Drake P, Baldo F, Saenz V, Arias, AM (1999) Macrobenthic community structure in estuarine pollution assessment on the Gulf of Cadiz (SW Spain): is the phylum-level metaanalysis approach applicable? Mar Pollut Bull 18: 1038-1047

Dukes JS, Mooney HA (1999) Does global change increase the success of biological invaders? Trends Ecol Evol 14: 135-139

Dunstan PK, Johnson CR (2004) Invasion rates increase with species richness in a marine epibenthic community by two mechanisms. Oecologia 138:285-292

Fauvel P (1923) Un nouveau serpulien d'eau saumatre Mercierella n.g. enigmatica n. sp. Bull Soc Zool Fr 46: $424-430$

Fornos JJ, Forteza V, Martinez-Taberner A (1997) Modern polychaete reefs in Western Mediterranean lagoons: Ficopomatus enigmaticus (Fauvel) in the Albufera of Menorca, Balearic Islands. Palaeogeogr Palaeoclimatol Palaeoecol 128:175-186

Foss A, Siikavuopio SI, Saether B, Evenson TH (2004) Effect of chronic ammonia exposure on growth in juvenile Atlantic cod. Aquaculture 237:179-189

Fox MJ, Fox BJ (1986) Susceptibility of natural communities to invasion. In: Groves RH, Burdon JJ (eds) Ecology of biological invasions. Cambridge University Press, Cambridge, p 57-66

Gamenick I, Jahn A, Vopel K, Giere O (1996) Hypoxia and sulphide as structuring factors in a macrozoobenthic community on the Baltic Sea shore: colonization studies and tolerance experiments. Mar Ecol Prog Ser 44:73-85

Graham KR, Sebens KP (1996) The distribution of marine invertebrate larvae near vertical surfaces in the rocky subtidal zone. Ecology 77:933-949

Gray JS, Shiu-sun Wu R, Or YY (2002) Effects of hypoxia and organic enrichment on the coastal marine environment. Mar Ecol Prog Ser 238:249-279

Haas LW (1977) The effect of the spring-neap tidal cycle on the vertical salinity structure of the James, York, and Rappanahannock Rivers, Virginia, USA. Estuar Coast Mar Sci 5:485-490

Hagerman L, Josefson AB, Jensen JN (1996) Benthic macrofauna and demersal fish. In: Jørgenson BB, Richardson K (eds) Eutrophication in coastal marine ecosystems, Vol 52. 
American Geophysical Union, Washington, DC, p 155-178 Heip C (1995) Eutrophication and zoobenthos dynamics. Ophelia 41:113-136

Jewett EB (2005) Epifaunal disturbance by periodic low DO: native vs. invasive species response. $\mathrm{PhD}$ dissertation, University of Maryland, College Park, MD

Johnston EL, Keough MJ (2003) Competition modifies the response of organisms to toxic disturbance. Mar Ecol Prog Ser 251:15-26

Karlson K, Rosenberg R, Bonsdorff E (2002) Temporal and spatial large-scale effects of eutrophication and oxgen deficiency on benthic fauna in Skandinavian and Baltic waters - a review. Oceanogr Mar Biol Annu Rev 40: 427-489

Kuo AY, Neilson BJ (1987) Hypoxia and salinity in VA estuaries. Estuaries 10:277-283

Laine AO (2003) Distribution of soft-bottom macrofauna in the deep open Baltic Sea in relation to environmental variability. Estuar Coast Shelf Sci 57:87-97

Llanso RJ (1992) Effects of hypoxia on estuarine benthos: lower Rappahanock River. Estuar Coast Shelf Sci 35: 491-515

Mann R, Rainer JS (1988) The response of swimming and metamorphosing oyster larvae to low dissolved oxygen. J Shellfish Res 7:168

Marcus NH (2001) Zooplankton: responses to and consequences of hypoxia. In: Rabalais NN, Turner RE (eds) Coastal hypoxia: consequences for living resources and ecosystem. American Geophysical Union, Washington, DC

Menge BA, Sutherland JP (1987) Community regulation: variation in disturbance, competititon, and predation in relation to environmental stress and recruitment. Am Nat 130:730-757

Miller TE (1982) Community diversity and interactions between the size and frequency of disturbance. Am Nat 120:533-536

Mirza FB, Gray JS (1981) The fauna of benthic sediments from the organically enriched Oslofjord, Norway. J Exp Mar Biol Ecol 54:181-207

Nandakumar K (1996) Importance of timing of panel exposure on the competitive outcome and succession of sessile organisms. Mar Ecol Prog Ser 131:191-203

Nestlerode JA, Diaz RJ (1998) Effects of periodic environmental hypoxia on predation of a tethered polychaete, Glycera americana: implications for trophic dynamics. Mar Ecol Prog Ser 172:185-195.

Nixon SW (1990) Marine eutrophication: a growing international problem. Ambio 19:101

Officer CB, Biggs RB, Taft JL, Cronin LE, Tyler MA, Boynton WR (1984) Chesapeake Bay anoxia: origin, development, and significance. Science 223:22-27

Otsuka CM, Dauer DM (1982) Fouling community dynamics in Lynnhaven Bay, Virginia. Estuaries 5:10-22

Pearson TH, Rosenberg R (1978) Macrobenthic succession in relation to organic enrichment and pollution of the marine environment. Oceanogr Mar Biol Annu Rev 16:229-311

Pertola S, Kuosa H, Olsonen R (2005) Is the invasion of Prorocentrum minimum (donphyceae) related to the nitrogen enrichment of the Baltic Sea? Harmful Algae 4:481-492

Petraitis PS, Latham RE, Niesenbaum RA (1989) The maintenance of species diversity by disturbance. Q Rev Biol 64: 393-418

Powilleit M, Kube J (1999) Effects of severe oxygen depletion on macrobenthos in the Pomeranian Bay (southern Baltic Sea): a case study in a shallow, sublittoral habitat charac- terized by low species richness. J Sea Res 42:221-234

Purcell JE, Breitburg DL, Decker MB, Graham WM, Youngbluth MJ Raskoff KA (2001) Pelagic cnidarians and ctenophores in low dissolved oxygen environments: a review. In: Rabalais NN, Turner RE (eds) Coastal hypoxia: consequences for living resources and ecosystem 58. American Geophysical Union, Washington DC

Rabalais NN, Turner Jr RE, Wiseman JW, Boesch DF (1991) A brief summary of hypoxia on the northern Gulf of Mexico continental shelf: 1985-1988. In: Tyson RV, Pearson TH (eds) Modern and ancient continental shelf anoxia. Geological Society (Spec Publ 58), London, p 35-46

Richards HG (1931) Notes on the marine invertebrate fauna of the Virgina Capes. Ecology 12:443-445

Rinkevich B, Paz G, Douek J, Ben-Shlomo R (2001) Allorecognition and microsatellite allele polymorphism of Botryllus schlosseri fom the Adriatic Sea. In: Sawada H, Yokosawa $\mathrm{H}$, Lambert CC (eds) The biology of ascidians. SpringerVerlag, Tokyo, p 426-435

Sagasti A, Schaffner LC, Duffy JE (2000) Epifaunal communities thrive in an estuary with hypoxic episodes. Estuaries $23: 474-487$

Sagasti A, Schaffner LC, Duffy JE (2001) Effects of periodic hypoxia on mortality, feeding and predation in an estuarine epifaunal community. J Exp Mar Biol Ecol 258: $257-283$

Sagasti A, Schaffner LC, Duffy JE (2003) Estuarine epifauna recruit despite hypoxic stress. Mar Biol 142:111-1 22

Sanford LP, Sellner KG, Breitburg DL (1990) Covariability of dissolved oxygen with physical processes in the summertime Chesapeake Bay. J Mar Res 48:567-590

Schiedek D (1997) Marenzelleria viridis (Verrill, 1873) (Polychaeta), a new benthic species within European coastal waters. Some metabolic features. J Exp Mar Biol Ecol 211: 85-101

Sebens KP (1986) Spatial relationships among encrusting marine organisms in the New England subtidal zone. Ecol Monogr 56:73-96

Sokal RR, Rohlf FJ (1995) Biometry. The principles and practice of statistics in biological research, 3rd edn. WH Freeman, New York

Sousa WP (1984) The role of disturbance in natural communities. Annu Rev Ecol Syst 15:351-391

Stachowicz JJ, Whitlatch RB, Osman RW (1999) Species diversity and invasion resistance in a marine ecosystem. Science 286:1577-1579

Stachowicz JJ, Terwin J.R, Whitlatch RB, Osman RW (2002) Linking climate change and biological invasions: ocean warming facilitates nonindigenous species invasion. Proc Natl Acad Sci USA 99:15497-15500

Stoner DS, Ben-Shlomo R, Rinkevich B, Wiessman I (2002) Genetic variability of Botryllus schlosseri invasions to the east and west coasts of the USA. Mar Ecol Prog Ser 243:93-100

Suzuki T (2001) Oxygen-deficient waters along the Japanese coast and their effects upon the estuarine ecosystem. J Environ Qual 30:291-302

Toonen RJ, Pawlik JR (2001) Settlement of the gregarious tube worm Hydroides dianthus (Polychaeta: Serpulidae). I. Gregarious and nongregarious settlement. Mar Ecol Prog Ser 224:103-114

Verrill AE (1898) Descriptions of new American actinians, with critical notes on other species. Am J Sci 4:493-498

Zibrowius H (1991) On-going modification of the Mediterranean marine fauna and flora by the establishment of exotic species. Mésogée 51:83-107 